\title{
Land Suitability Evaluation for Blueberry Crop by Determining the Qualitative Properties of the Identified Soil Type Related with the Antioxidant Capacity of Fruits
}

\author{
Amalia Ioana BOT, ${ }^{1 *}$, Ioan PĂCURAR ${ }^{1}$, Lech W. SZAJDAK ${ }^{2}$, \\ Viorela PLEȘA ${ }^{1}$, Sanda ROȘCA ${ }^{3}$, Ștefan BILAȘCO ${ }^{3,4}$ \\ ${ }^{1}$ University of Agricultural Sciences and Veterinary Medicine, 3-5 Manastur Street, 400372, Cluj-Napoca, \\ Romania; bot.amaliaioana@gmail.com (*correspondingauthor); ioanpacurarcj@yahoo.com \\ ${ }^{2}$ Institute of Agricultural and Forest Environment, Polish Academy of Sciences, 19 Bukowska Street, 60-809, Poznan, \\ Poland; lech.szajdak@isrl.poznan.pl \\ ${ }_{3}^{3}$ Babeș-Bolyai University, Faculty of Geography, 5-7 Clinicilor Street, 400006, Cluj-Napoca, Romania; rosca_sanda@yahoo.com \\ ${ }^{4}$ Romanian Academy Romanian Academy, Cluj-Napoca Subsidiary Geography Section, 9 Republicii Street, 400015 Cluj-Napoca, \\ Romania; stefan.bilasco@ubbcluj.ro
}

\begin{abstract}
Organic and inorganic forms of nitrogen and carbon were measured in order to determine soil fertility. The amount of total nitrogen ranged between $0.849 \mathrm{~g} / \mathrm{kg}$ and $1.755 \mathrm{~g} / \mathrm{kg}$ in the samples gathered from soil in modified state and between $0.961 \mathrm{k} / \mathrm{kg}$ and $2.427 \mathrm{~g} / \mathrm{kg}$ in the samples collected from the soil in natural state. Based on these results it could be concluded that in comparing with the previous year, plants used the soil nutrients for their development. The activities of different enzymes were measured as well. Nitrate reductase activity was also higher in samples collected from soil in modified state (from bilon) than in the samples collected near plantations (control samples) and the values ranged between $0.055 \pm 0.012$ $\mu \mathrm{mol} \cdot \mathrm{h}^{-1} \cdot \mathrm{g}^{-1}$ and $1.018 \pm 0.117 \mu \mathrm{mol} \cdot \mathrm{h}^{-1} \cdot \mathrm{g}^{-1}$ in samples from soil in natural state and between $0.013 \pm 0.002 \mu \mathrm{mol} \cdot \mathrm{h}^{-1} \cdot \mathrm{g}^{-1}$ and $0.447 \pm 0.083 \mu \mathrm{mol} \cdot \mathrm{h}^{-1} \cdot \mathrm{g}^{-1} \mathrm{n}$ bilons. Using GIS techniques of spatial analysis to determine the exact type of soil from each studied blueberry plantation from the Northwest Region of Development and also based on the soil bio-chemical analyses, it was possible to achieve a qualitative characterization of the territory, taking into account the requirements of blueberries for cultivation and to achieve a land suitability for blueberry crop. Combining laboratory approach, consisting from soil biochemical and physico-chemical analyses and chemical analyses of blueberry fruits, with the techniques used in order to determine the soil type and land suitability, the study conducted in the Northwest Region of Development identified the best conditions for blueberry crop, based on the qualitative characterization of land.
\end{abstract}

Keywords: bio-chemical compounds, correlations, land evaluation, polyphenols, seasonal variety

\section{Introduction}

One of the most burning problems of humanity refers to sustainable development. Agricultural practices have become more and more relevant in national and local policies. New national approaches regarding land management aim land's agricultural capitalization (GAEC, 2003, according to the National Strategic Framework for sustainable development of the agro-alimentary sector and the rural area in the interval 2014-2020-2030). The economical approach to land capability classification was developed by the German school for the ecological and economical land zonation, while the Russian school focused on researching and implementing a land classification based on fertility as a consequence of the studies performed by the pedologists V. V. Dokuceaev and N. M. Sibirțev (Aparaschivei, 2012). In the same year, Storie Earl, who was considered the father of the American school of land capability classification, created the Storie system of land classification which considered both the soil characteristics and the natural conditions of the territory (Aparaschivei, 2012).

Studies concerned with the subject of land capability classification and soil resources were created by Teaci $e t a l$. (1972, 1989), Cernescu et al. (1989, 1999), Munteanu et al. 
572

(2000), Păcurar and Buta (2007), often focusing also on the climate's influence (Berbecel et al., 1984; Untaru and Vespremeanu, 1994). The results of various studies draw the attention upon the decrease of land productivity due to climatic changes and the surface increase of degraded land in spite of an increase in the number of inhabitants and thus of necessity (Briza et al., 2001; Behzad et al., 2009; Teklu, 2005; Henok, 2010; Păcurar et al., 2013; Bilașco et al., 2016). Studies highlight the influence of slope, slope orientation and landform altitude, factors that have a particular influence on the growth and cultivation of the blueberry, as noted in studies conducted by Oprea (1962), Cernescu et al. (1964-1994), Amzar (1973), Merlescu and Teşu (1982), Barbu (1987), Forney et al. (2002), Rusu et al. (2009), Bilaşco (2010), Cedar (2014).

One of the most suitable tools for soil analysis regarding his favorability and the suitability of land for different agricultural uses is spatial modulation in GIS, which uses a number of several factors for creating raster database, accordingly to the specifics of crop. The spatial modelling of field suitability to various agricultural cultures requires the use of several techniques and methods of spatial analysis which rely on specialized software and the manipulation of thematic layers by means of mathematical equations transformed into GIS equations and functions of spatial analysis used to generate new attributes stored in various databases (Petrea et al., 2014). The map used as technical support is the Romanian Map Soil, from 1960, which is constantly updated by Pedological Office for Agrochemical Studies.

Vaccinium corymbosum L., a native species of North America, is also found in spontaneous flora, most likely in mountain areas, coniferous forests, on soils from Romania with acid $\mathrm{pH}$ and sunny exposure, but increasingly appears to be used in intensive crops, which demonstrates the awareness of the farmers in regard to its economic potential and the antioxidant properties of fruits, as well as the beneficial effects brought on the body, reinforced by the recent medical studies. A series of studies, regarding the factors that have an influence regarding the antioxidant capacity of fruit such as crop technology, application of fertilizers and pesticides, conditions for harvesting and storing fruit or suitability conditions about meteorological data from the ripening period, were carried out by Lara Gibson et al. (2013), Eichholzl et al. (2012), Warman and Shanmugam (2008), Wang (2006), Verica Dragovic-Uzelac et al. (2010), Cardenosa et al. (2016) and many others.

Given the studies presented and also considering the fact that agricultural practices and cultivars play a key role in the development of the territory, we hereby conducted the following research in order to determine the suitability of land from Northwest Region of Development (Romania) for the blueberry crop, cultivation that gains interest year after year and has major impact on the economic approach for the sustainable development of territory.

\section{Materials and Methods}

The evaluation of land suitability for blueberry crop was studied by determining the qualitative properties of the soil in relation with the antioxidant capacity of fruits. Data collection regarding, soil, climate, landforms, geographical and pedological factors, used in map modelling was based on numerous specialized studies, processed data of local weather stations, various information from the National Weather Institute, cartographic Romanian Soil Map. All this gathered information has generated a digitized map used in order to identify soil suitability. The methodology for land favorability, established by the National Research Institute for Pedological Studies was used in order to identify soil suitability. The GIS techniques used for spatial interpretation offer the possibility to trace value variation of soil parameters. In order to obtain a grid with the average annual temperature, the same GIS data base technology, used in similar studies, stood at the elaboration procedure, along with a processed database obtained from local weather stations, which lead to a new database - grid type, raster format, that will be used in the complex methodology that identifies soil suitability.

In order to determine the qualitative properties of soils from the studied fields, soil samples were collected from eight different blueberry crops owned by farmers from the Northwest Region of Development from Romania (Table 1). Soil samples were taken from the layer of $0-20 \mathrm{~cm}$ after removal of leaf litter from every measuring point. Samples were air-dried and crushed to pass through a $1 \mathrm{~mm}$ mesh sieve.

The $\mathrm{pH}$ of soil samples was measured in water (1:2.5 $\mathrm{v} / \mathrm{v}$ ) suspensions applying the potentiometric method using combination electrode by $\mathrm{pH}$-meter $\mathrm{CP}-501$, Elmetron (Poland).

For the investigation of TOC and DOC, $50 \mathrm{mg}$ of soil sample was set in Total Organic Carbon Analyzer TOC5050A (Shimadzu, Japan), equipped with Liquid and Solid Sample Module SSM-5000A (Shimadzu, Japan) and the content was measured.

$\mathrm{N}$-total was evaluated by Kjeldahl method. The concentrations of $\mathrm{N}$-total were calculated:

$$
\begin{aligned}
& \mathrm{N} \text {-total }=\mathrm{V}_{\text {HCl }} \cdot 0.28 \cdot 800[\mathrm{mg} / 100 \mathrm{gd} . \mathrm{m} .] \\
& \mathrm{n} / \mathrm{N}-\frac{\mathrm{N} \text {-total }}{1000},
\end{aligned}
$$

where: $\mathrm{V}_{\mathrm{HCl}}$ - the volume of $0.02 \mathrm{M} \mathrm{HCl}[\mathrm{ml}], 0.28-$ conversion factor $(1 \mathrm{ml}$ of $0.02 \mathrm{M} \mathrm{HCl}$ corresponds to 0.28 $\mathrm{mg}$ of nitrogen), 800 - conversion factor corresponded to: (I) volume of flask $(100 \mathrm{ml})$; (II) weight of soil sample $(0.5$ g); (III) volume of mineralized sample $(25 \mathrm{ml})$.

The concentrations of $\mathrm{N}$-organic were calculated from equation:

\section{$\mathrm{N}$-organic $=\mathrm{N}$-total $-\mathrm{N}-\mathrm{NH}_{4}^{+}[\mathrm{mg} / \mathrm{l}]$,}

where: $\mathrm{N}^{-\mathrm{NO}_{3}}$ was evaluated by chromatographic method on ion chromatograph HIC-6A Shimadzu (Japan). $\mathrm{N}-\mathrm{NH}_{4}^{+}$was evaluated by chromatographic method, on ion chromatograph Waters 1515 (USA). Slope coefficient of $\mathrm{N}-\mathrm{NO}_{3}^{-}$and $\mathrm{N}-\mathrm{NH}_{4}^{+}$was calculated as the slope of the analytical curve by means of the least squares formulas. The retention time is equal to $6.5 \mathrm{~min}$.

$\mathrm{Ar}=\mathrm{a} \cdot \mathrm{c}$,

where: $\mathrm{Ar}$ - area under peak, a - slope coefficient $[1 / \mathrm{mol}]$, c- concentration $[\mathrm{mol} / \mathrm{l}]$. 
For determining the qualitative properties of fruits, total phenolic, total polyphenols and antioxidant capacity assay were made. Total phenolic content were measured using the Folin-Ciocalteau colorimetry protocol with some minor modifications from Singleton et al. (1999). Total phenolic content was calculated as gallic acid equivalents (GAE) based on the gallic acid calibration curve.

The total flavonoid content of the extracts was determined by a colorimetric method as described previously in other studies. A $1 \mathrm{~mL}$ aliquot of appropriately diluted extract was added to a $5 \mathrm{~mL}$ volumetric flask. At zero time, $300 \mu \mathrm{l}$ of $5 \% \mathrm{NaNO}_{2}$ was added to the flask. After 5 min incubation, the mixture was treated with $300 \mu \mathrm{l}$ $\mathrm{AlCl}_{3}(10 \%)$ and incubated for $6 \mathrm{~min}$. Then, $2 \mathrm{ml}$ of $1 \mathrm{M}$ $\mathrm{NaOH}$ was added. The solution was mixed well and the absorbance at $720 \mathrm{~nm}$ versus water blank was recorded using a spectrophotometer (JASCO V-630 series, International Co., Ltd., Japan). The flavonoid content was expressed as $\mathrm{mg}$ quercetin equivalents $/ 100 \mathrm{~mL}$ juice.

The determination of the antioxidant capacity was made using the 2,2'-azino-bis (3-ethlylbenzothiazoline-6-sulfonic acid) (ABTS) radical cation-decolorization assay method. Blue-green color ABTS + solution was obtained by mixing $5 \mathrm{~mL}$ of $7 \mathrm{mM} \mathrm{ABTS}+$ and $80 \mu \mathrm{L}$ of $2.45 \mathrm{mM}$ potassium persulfate. The reaction was carried out in the dark at room temperature for $16 \mathrm{~h}$ before its use. ABTS + working solution was obtained by the diluting the stock solution with ethanol, in order to obtain an absorbance of $0.70 \pm$ $0.02 \mathrm{AU}$ at $734 \mathrm{~nm}$. Once the working solution is prepared, $20 \mu \mathrm{l}$ Trolox at different concentrations or fruit extract were added to $170 \mu \mathrm{l}$ ABTS + solutions and the absorbance was measured at $734 \mathrm{~nm}$ after 6 minutes of incubation in dark at room temperature using a micro plate reader. Results were expressed as $\mu \mathrm{mol}$ Trolox/g FW. For each determination, the assay was carrying out in triplicate.

\section{Results}

From the table below, plantations from Galații Bistriței, Cetariu, Ulmeni, Copalnic and Ardud present the proper C: $\mathrm{N}$ ratio for mineralization process, meaning that plants absorb more easily nutrients from soil. On the other hand, the enzymes that influence mineralization were also found in larger quantities. Talking about the amount of nitrogen, the results are quite similar for all plantations, with higher amounts in Galații Bistriței, Cetariu and Ardud (Table 1), both for organic and inorganic forms.

Regarding the results of case studies on soil suitability presented under the shape of maps, which are much easier to read and useful in conducting a conclusion, research on favorability states that plantations located in Cetariu and Sintereag provide the most suitable conditions for blueberry. Further, soil type from this areas, albic and typical luvosol, present natural conditions of acidity, proper for development of blueberry. Regarding the differences between plantations, from the figures below we can state out that, regarding the favorability of soil for blueberry crop, the best location, are in Şintereag and Cetariu, followed closely by Mărișel, Galații Bistriței and Ardud (Fig. 1).

In order to establish the antioxidant capacity of blueberry fruits, there were used 3 types of analisys: phenolic content; total flavonoid content and ABTS extraction (Figs. 2,3 and 4).

Regarding the relationships between the parameters determined in soil, based on the significant correlation coefficient test, performed in Microsoft Excel- Data Analysis - Person Correlation $(\mathrm{n}=8, \mathrm{p} \geq 0.05)$, a strong significant correlation are met between total organic carbon, total nitrogen and C:N, suggesting once more that this ratio is very strongly connected with the compounds that relays on (Ge et al., 2013).

Table 1. Soil analyzed parameters (mean value \pm SD) in eight different blueberry crops owned by farmers from the Northwest Region of Development from Romania

\begin{tabular}{|c|c|c|c|c|c|c|c|c|}
\hline Sample/Analyze & Şintereag & $\begin{array}{l}\text { Galații } \\
\text { Bistriței }\end{array}$ & Cetariu & Mărişel & Ulmeni & Copalnic & Ardud & Zimbor \\
\hline $\mathrm{pH}$ & 5.00 & 7.40 & 5.40 & 4.90 & 7.00 & 5.40 & 6.60 & 6.40 \\
\hline Total N (g/kg) & $1.68 \pm 0.24$ & $1.75 \pm 0.46$ & $0.90 \pm 0.24$ & $1.75 \pm 0.09$ & $1.34 \pm 0.24$ & $1.47 \pm 0.05$ & $1.68 \pm 0.28$ & $1.66 \pm 0.12$ \\
\hline $\mathrm{NO}_{3-}(\mathrm{mg} / \mathrm{kg})$ & $14.67 \pm 0.34$ & $31.67 \pm 0.97$ & $3.66 \pm 0.13$ & $31.67 \pm 1.23$ & $7.15 \pm 0.53$ & $30.30 \pm 0.42$ & $14.67 \pm 0.66$ & $24.47 \pm 0.97$ \\
\hline $\mathrm{NH}_{4+}(\mathrm{mg} / \mathrm{kg})$ & $1.48 \pm 0.09$ & $9.37 \pm 0.68$ & $3.38 \pm 0.09$ & $9.37 \pm 0.29$ & $2.18 \pm 0.09$ & $6.60 \pm 0.54$ & $1.48 \pm 0.28$ & $12.07 \pm 0.53$ \\
\hline TOC (g/kg) & $28.36 \pm 0.98$ & $26.40 \pm 1.21$ & $9.32 \pm 0.78$ & $26.40 \pm 0.77$ & $19.85 \pm 0.98$ & $21.83 \pm 1.29$ & $28.36 \pm 0.28$ & $51.64 \pm 0.29$ \\
\hline DOC $(\mathrm{g} / \mathrm{kg})$ & $1.25 \pm 0.23$ & $2.06 \pm 0.35$ & $0.80 \pm 0.23$ & $2.06 \pm 0.06$ & $1.19 \pm 0.23$ & $1.22 \pm 0.14$ & $1.25 \pm 0.28$ & $3.06 \pm 0.14$ \\
\hline $\mathrm{C}: \mathrm{N}$ & 13 & 12 & 8 & 24 & 12 & 12 & 13 & 31 \\
\hline $\mathrm{Fe}^{2+}(\mathrm{mg} / \mathrm{kg})$ & $1.42 \pm 0.19$ & $6.97 \pm 0.79$ & $7.45 \pm 0.19$ & $6.97 \pm 0.40$ & $9.34 \pm 0.19$ & $3.93 \pm 0.48$ & $1.42 \pm 0.28$ & $10.36 \pm 0.82$ \\
\hline $\mathrm{Fe}^{3+}(\mathrm{mg} / \mathrm{kg})$ & $21.07 \pm 0.54$ & $11.24 \pm 0.96$ & $12.09 \pm 0.54$ & $11.24 \pm 0.62$ & $11.17 \pm 0.54$ & $4.43 \pm 0.78$ & $21.07 \pm 0.28$ & $10.20 \pm 0.54$ \\
\hline $\begin{array}{l}\text { Urease activity } \\
\left(\mu \mathrm{m} \cdot \mathrm{h}^{-1} \cdot \mathrm{g}^{-1}\right)\end{array}$ & $1.28 \pm 0.26$ & $3.23 \pm 0.51$ & $1.41 \pm 0.26$ & $3.23 \pm 0.12$ & $0.72 \pm 0.26$ & $1.49 \pm 0.64$ & $1.28 \pm 0.28$ & $0.16 \pm 0.15$ \\
\hline $\begin{array}{c}\text { Nitrate reductase } \\
\left(\mu \mathrm{gN} \cdot \mathrm{g}^{-1} \cdot 24 \mathrm{~h}^{-1}\right)\end{array}$ & $0.14 \pm 0.03$ & $0.18 \pm 0.03$ & $0.07 \pm 0.03$ & $0.18 \pm 0.01$ & $0.30 \pm 0.03$ & $0.06 \pm 0.01$ & $0.14 \pm 0.08$ & $0.37 \pm 0.08$ \\
\hline Phenol oxidase $\left(\mu \mathrm{m} \cdot \mathrm{h}^{-1} \cdot \mathrm{g}^{-1}\right)$ & $8.34 \pm 0.73$ & $25.32 \pm 0.99$ & $13.43 \pm 0.73$ & $25.32 \pm 0.82$ & $15.32 \pm 0.73$ & $12.69 \pm 1.62$ & $8.34 \pm 0.28$ & $21.01 \pm 0.49$ \\
\hline $\begin{array}{l}\text { Xanthine oxidase } \\
\left(\mu \mathrm{m} \cdot \mathrm{h}^{-1} \cdot \mathrm{g}^{-1}\right)\end{array}$ & $4.67 \pm 0.39$ & $4.44 \pm 0.46$ & $4.49 \pm 0.39$ & $4.44 \pm 0.16$ & $4.80 \pm 0.39$ & $5.11 \pm 0.05$ & $4.67 \pm 0.28$ & $5.60 \pm 0.41$ \\
\hline $\begin{array}{l}\text { Peroxidase } \\
\left(\mu \mathrm{m} \cdot \mathrm{h}^{-1} \cdot \mathrm{g}^{-1}\right)\end{array}$ & $0.66 \pm 0.04$ & $2.37 \pm 0.28$ & $0.69 \pm 0.04$ & $2.37 \pm 0.10$ & $1.31 \pm 0.04$ & $0.56 \pm 0.04$ & $0.66 \pm 0.28$ & $6.96 \pm 0.09$ \\
\hline
\end{tabular}



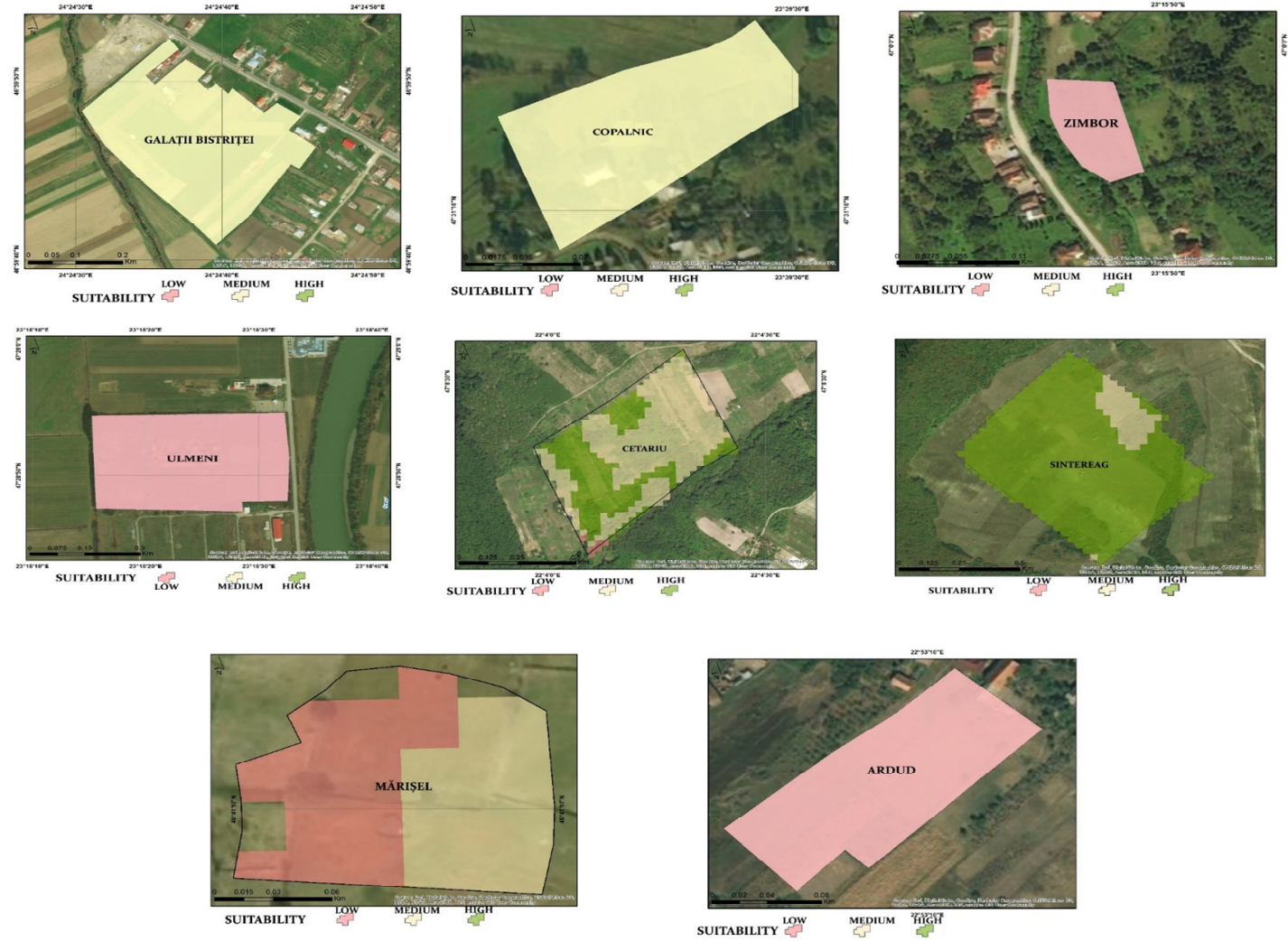

Fig. 1. Favourability classes for blueberry plantation (original) in Northwest Region of Development from Romania

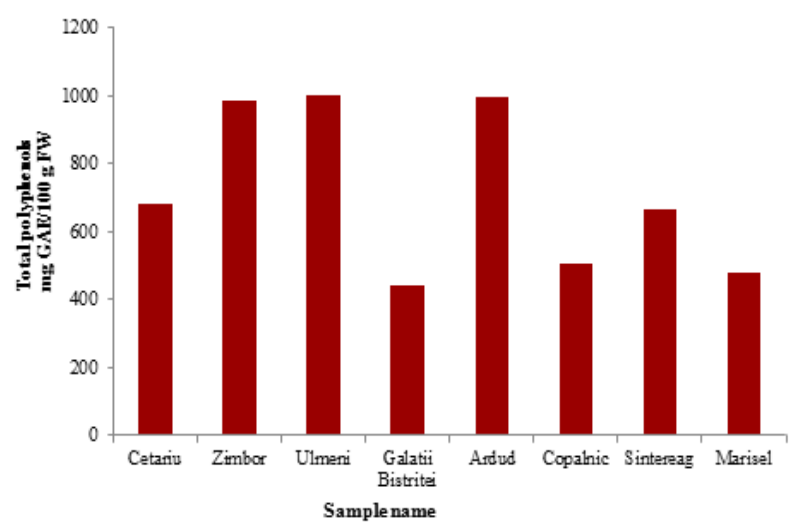

Fig. 2. Antioxidant capacity of blueberry fruits - phenolic content, depending of locations

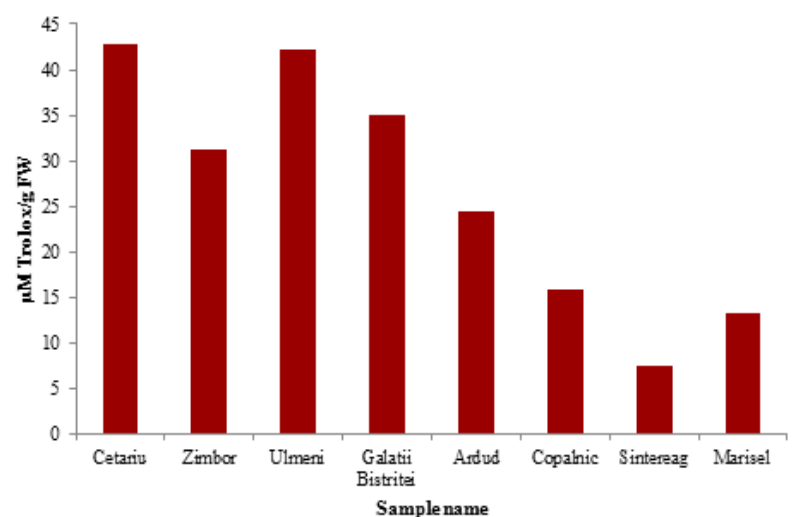

Fig. 4. Antioxidant capacity of blueberry fruits - ABTS extraction, depending of locations

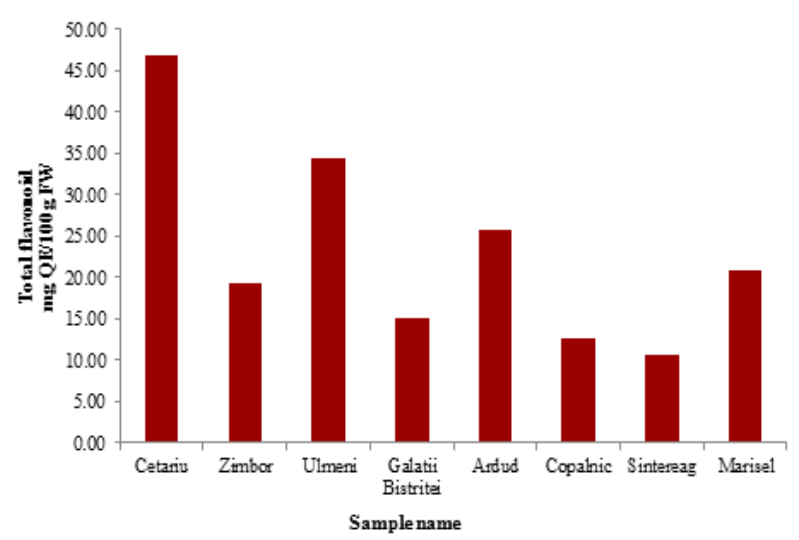

Fig. 3. Antioxidant capacity of blueberry fruits - total flavonoid content, depending of locations

Also, a strong correlation was noticed for the nitrate reductase activity enzyme on the organic and mineral forms of nitrogen (Caldwel, 2005).

\section{Discussion}

The analyses conducted revealed the importance of knowing the concentrations of total nitrogen in soil and total organic carbon, compound that play a key role in choosing the best fertility plan for each plantation and also the amendments needed in soil, depending on the requirement of blueberry plant. Furthermore, the results obtained on $\mathrm{C}: \mathrm{N}$ ratio and $\mathrm{pH}$ showed that, indeed, $\mathrm{pH}$ has an influence on the value of $\mathrm{C}: \mathrm{N}$ ratio, but also influences the values of total nitrogen and the processes of mineralization and nitrification, because $\mathrm{pH}$ influence the 
Table 2. Significant correlation coefficient for samples from plantation

\begin{tabular}{|c|c|c|c|c|c|c|c|c|c|c|c|c|c|c|}
\hline $\mathrm{R}$ & $\mathrm{pH}$ & $\mathrm{N}_{\text {total }}$ & $\mathrm{NO}_{3+}$ & $\mathrm{NH}_{4}$ & TOC & DOC & C:N & $\mathrm{Fe}^{2+}$ & $\mathrm{Fe}^{3+}$ & Urease & Nit. Red. & $\begin{array}{c}\text { Phen. } \\
\text { Ox. }\end{array}$ & $\begin{array}{c}\text { Xant. } \\
\text { Ox. }\end{array}$ & Perox. \\
\hline $\mathrm{pH}$ & - & 0.131 & 0.198 & 0.339 & 0.026 & 0.079 & 0.017 & 0.734 & -0.112 & -0.043 & $0.642^{*}$ & 0.772 & -0.076 & 0.331 \\
\hline $\mathrm{N}_{\text {total }}$ & & - & 0.444 & 0.480 & $0.724^{*}$ & 0.657 & $0.558^{*}$ & -0.312 & 0.127 & 0.335 & 0.250 & 0.277 & 0.306 & 0.288 \\
\hline $\mathrm{NO}_{3+}$ & & & - & 0.574 & 0.340 & 0.353 & 0.279 & -0.031 & $-0.414^{*}$ & 0.197 & 0.040 & 0.501 & 0.248 & 0.410 \\
\hline $\mathrm{NH}_{4-}$ & & & & - & $0.697^{*}$ & $0.789^{* *}$ & 0.681 & 0.363 & $-0.478^{*}$ & 0.129 & 0.356 & $0.758^{* *}$ & $0.568^{*}$ & $0.746^{* *}$ \\
\hline TOC & & & & & & 0.913 & $0.975^{* *}$ & 0.087 & -0.025 & -0.129 & $0.558^{*}$ & 0.337 & $0.756^{* *}$ & $0.784^{* *}$ \\
\hline DOC & & & & & & - & $0.877^{* *}$ & 0.129 & -0.213 & 0.168 & 0.430 & 0.529 & $0.595^{*}$ & $0.748^{* *}$ \\
\hline $\mathrm{C}: \mathrm{N}$ & & & & & & & - & 0.226 & -0.083 & -0.299 & $0.625^{*}$ & 0.316 & $0.837^{* *}$ & $0.857^{* *}$ \\
\hline $\mathrm{Fe}^{2+}$ & & & & & & & & - & -0.268 & -0.477 & $0.730^{*}$ & 0.627 & 0.251 & $0.591^{*}$ \\
\hline $\mathrm{Fe}^{3+}$ & & & & & & & & & - & -0.101 & 0.094 & -0.344 & -0.390 & -0.168 \\
\hline Urease & & & & & & & & & & - & -0.559 & 0.243 & -0.536 & -0.368 \\
\hline Nit. Red. & & & & & & & & & & & - & 0.484 & 0.495 & 0.743 \\
\hline Phen.Ox. & & & & & & & & & & & & - & 0.084 & 0.624 \\
\hline Xant. Ox. & & & & & & & & & & & & & - & 0.674 \\
\hline Perox. & & & & & & & & & & & & & & - \\
\hline
\end{tabular}

microorganism activity which is responsible for these processes.

The major class soil identified, cambisol, luvisol and cernisol, the results obtained on total nitrogen are and total organic carbon are typical for these soil classes considering their major characteristics and description, thus the plantations from Cetariu, Copalnic and Mărișel meet the maximum favorability for blueberry crop, have the better results in matter of nutrients in soil and also, the soil type identified (typical luvisol and distric cambisol) provide better conditions for this culture.

\section{Conclusions}

Combining two methods of analyzing soil favorability from two different approaches, it was possible to obtain similar results. Land favorability determined by using GIS techniques and the bio-chemical analyses conducted on soil revealed that plantations located in Catariu and Marisel provide better conditions regarding the nutrient from soil and also the high/medium favorability obtained in GIS modeling that used as database nine variables, such as $\mathrm{pH}$, texture, slope inclination, altitude, annual average temperatures and rainfall, slope orientation, type of soil, land use and bioactive period for blueberry, all of these factors were given accordingly to blueberry requirements for cultivation. As a final state, the types of soil highly recommended for establishing blueberry cultivation are albic and typical luvosol or distric cambosol. The results obtained showed that these types of soils can provide better conditions, conclusion strengthened by the high/medium favorability obtained. On the other hand, soil type aluvisol does not have good content in nutrients, nor a good favorability, the results concluded that farmers should not establish this crop on this type, because, amendments will not help in long term.

\section{References}

Aparaschivei O (2012). Quantitative determination of ecologic indices used for capability classification of mountain and premountain beech forests (FM1+FD4) in the Baraolt and Bodoc Mountains [in Romanian]. PhD thesis, Transylvania University from Braşov.

Bilaşco Ş, Roşca S, Păcurar I, Moldovan N, Boț A, Negrușier C, Sestras P, Bondrea M, Naş S (2016). Identification of Land Suitability for Agricultural Use by Applying Morphometric and Risk Parameters Based on GIS Spatial Analysis. Notulae Botanicae Horti Agrobotanici Cluj-Napoca 44(1):302-312.

Blaga G, Paulette L, Udrescu S, Filipov F, Rusu I, Vasile D (2008). Pedology [in Romanian].Editura Mega, Cluj-Napoca.

Bunea A, Rugină DO, Pintea AM, Sconța Z, Bunea CI, Socaciu C (2011). Comparative polyphenolic content and antioxidant activities of some wild and cultivated blueberries from Romania. Notulae Botanicae Horti Agrobotanici39(2):70-76.

Burns RG (1978). Soil enzymes. Academic Press, London.

Caldwell BA (2005). Enzyme activities as a component of soil biodiversity A review.Pedobiologia 49:637-644.

Cardeñosa V, Girones-Vilaplana A, Muriel JL, Moreno DA, Moreno-Rojas JM (2016). Influence of genotype, cultivation system and irrigation regime on antioxidant capacity and selected phenolic of blueberries (Vacinium corymbosum L.). Food Chemistry 202:276-283.

Clapa D (2006). Micropropagation of high bush cowberry (Vaccinium corymbosum) - a quick solution for the recovery of acidic soils [in Romanian]. Agricultura-Revista de stiinta si practica agricola 57:1-2.

Diaconeasa Z, Leopold L, Rugină D, Ayvaz H, Socaciu C (2015). Antiproliferative and antioxidant properties of anthocyanin rich extracts from blueberry and blackcurrant juice. International Journal of MolecularSciences 16(2):2352-2365.

Forney CF, Kalt W, Jordan MA, Vinqvist-Tymchu MR, Fillmore SAE (2012). Blueberry and cranberry fruit composition during development. Journal of Berry Research 2:169-177. 
576

Ge S, Xu H, Ji M, Jiang Y (2013). Characteristics of soil organic carbon, total nitrogen, and $\mathrm{C} / \mathrm{N}$ ratio in Chinese apple orchards. Open Journal of Soil Science 3(5):213-217.

Gunduz K, Serce S, Hancock JF (2015). Variation among highbush and rabbiteye cultivars of blueberry for fruit and phytochemical characteristics. Journal of Food Composition and Analysis 38:69-79.

Lupaşcu G (1998). Soil geography based on pedology elements [in Romanian]. Editura Universității AlI Cuza, Iaşi.

Magnoff F, Weil RR (2004). Soil organic matter in sustainable agriculture. Editura CRC Press, USA.

Mihalache M, Ilie L (2008). Pedology, Romanian soils [in Romanian]. Ed. Dominor, Bucureşti.

Mushtaq M, Wani SM (2013). Polyphenols and human health - A review. International Journal of Pharma and Bio Sciences 4(2):338-360.

Păcurar I, Buta M (2010). Pedology and agricultural lands bonitation [in Romanian].Ed.AcademicPres Cluj-Napoca.

Singleton VL, Orthofer R, Lamuela-Raventós RM (1999). Analysis of total phenols and other oxidation substrates and antioxidants by means of Folin-Ciocalteu reagent. Methodsin Enzymology 299:152-78.

Skrovankova S, Sumczynski D, Mlcek J, Jurikova T, Sochor J (2015). Bioactive compounds and antioxidant activity in different types of berries. International Journal of Molecular Sciences 16(10):2467324706.
Smolander A, Kitunen V, Malkonen E (2002). Dissolved soil organic nitrogen and carbon in a Norway spruce stand and an adjacent clear-cut. Biology and Fertility ofSoils 33:190-196.

Spârchez G (2009). Agricultural lands and forest bonitation [in Romanian]. Tipografia Universității,Brașov.

Stevenson FJ (1982). Humus chemistry - genesis, composition, reactions. John Wiley\&Sons, USA.

Szajdak LW, Karabanov AK (2010). Physical, chemical and biochemical processes in soils. Institute for Agricultural and Forest Environment. Polish Academy ofSciences, Poznan.

Szajdak LW, Meysner T, Styła K (2011b). Biochemical and chemical characterization of soils under shelterbelts and adjoining cultivated fields. In: Szajdak LW (Ed). Shalterbelts: efficient element of the landscape. Chemical and biochemical investigations of ground water and soil. LAP Lambert Academic Publishing. Saarbrücken, Germany pp 33-53.

Velioglu YS, Mazza G, Gao L, Oomah B (2016). Antioxidant activity and total phenolics in selected fruits, vegetables and grain products. Journal of Agricultural and Food Chemistry 46(10):4113-4117.

You Q, WangB, Chen F, HuangZ, WangX,LuoPG(2011). Comparison of anthocyanins and phenolics in organically and conventionally grown blueberries in selected cultivars. Food Chemistry 125(1):201-208. 